\title{
Article \\ Impact of Ageing on Pea Protein Volatile Compounds and Correlation with Odor
}

\author{
Estelle Fischer (D), Rémy Cachon and Nathalie Cayot*(iD) \\ AgroSup Dijon, Université Bourgogne Franche-Comté, PAM UMR A 02.102, F-21000 Dijon, France; \\ estelle.fischer@agrosupdijon.fr (E.F.); remy.cachon@agrosupdijon.fr (R.C.) \\ * Correspondence: nathalie.cayot@agrosupdijon.fr
}

Citation: Fischer, E.; Cachon, R.; Cayot, N. Impact of Ageing on Pea Protein Volatile Compounds and Correlation with Odor. Molecules 2022, 27, 852. https://doi.org/ $10.3390 /$ molecules 27030852

Academic Editors:

Elisabeth Guichard, Jean-Luc Le Quéré and Monica Rosa Loizzo

Received: 24 November 2021

Accepted: 25 January 2022

Published: 27 January 2022

Publisher's Note: MDPI stays neutral with regard to jurisdictional claims in published maps and institutional affiliations.

Copyright: (C) 2022 by the authors. Licensee MDPI, Basel, Switzerland. This article is an open access article distributed under the terms and conditions of the Creative Commons Attribution (CC BY) license (https:// creativecommons.org/licenses/by/ $4.0 /)$.

\begin{abstract}
Vegetal proteins are of high interest for their many positive aspects, but their 'beany' off-flavor is still limiting the consumer's acceptance. The aim of this work was to investigate the conservation of pea protein isolate (PPI) during time and especially the evolution of their organoleptic quality under two storage conditions. The evolution of the volatile compounds, the odor and the color of a PPI has been investigated during one year of storage. PPI was exposed to two treatments mimicking a lack of control of storage conditions: treatment A with light exposition at ambient temperature (A-Light $20^{\circ} \mathrm{C}$ ) and treatment $\mathrm{B}$ in the dark but with a higher temperature (B-Dark $\left.30{ }^{\circ} \mathrm{C}\right)$. For each sampling time $(0,3,6,9,12$ months), the volatile compounds were determined using HS-SPME-GC-MS, the odor using direct sniffing, and the color using the measurement of $\mathrm{L}^{*}$, $\mathrm{a}^{*}, \mathrm{~b}^{*}$ parameters. Treatment A was the most deteriorating and led to a strong increase in the total volatile compounds amount, an odor deterioration, and a color change. Furthermore, a tentative correlation between instrumental data on volatile compounds and the perceived odor was proposed. By the representation of volatile compounds sorted by their sensory descriptor, it could be possible to predict an odor change with analytical data.
\end{abstract}

Keywords: pea protein; storage conditions; aroma; HS-SPME-GC-MS; 'beany' off-flavor

\section{Introduction}

The demand for plant-based proteins is increasing due to their numerous positive effects [1-3]. Many studies are dealing with the sensory aspects of these proteins [4,5], especially the 'beany' off-flavor, as it is limiting the consumer's acceptance [6-8]. Numerous works are done on the off-flavor characterization, and on the impact of various processes on the profile in volatile compounds [9-13].

The typical 'beany' off-flavor, associated with 'green' and 'earthy' attributes, is a combination of different volatile compounds belonging to various chemical families like aldehydes, ketones, or alcohols [7,10]. These compounds are typically found in pulses or other legumes and are generated through different pathways, like enzymatic and nonenzymatic degradation of lipids, amino-acids and peptides $[6,14]$. Lipid oxidation starts early and rapidly after the harvest and during the first stages of the production of pea protein isolate (PPI) $[6,10]$. The 'beany' off-flavor is generated in early phases and can evolve during the storage.

Especially, this off-flavor can evolve quickly in PPI powder, becoming detrimental to the product. From the humidity/water activity $\left(\mathrm{a}_{\mathrm{w}}\right)$ relation to oxidation sensitivity, powders are highly sensible to lipid oxidation [15]. The lipid oxidation is very fast and can start since the harvest of the raw material. Lipids are rapidly converted into fatty acid hydroperoxydes (HPOD), leading to the formation of volatile and non-volatile compounds [16]. The primary products (HPOD) appear as early as seven days after the start of the cells breaking, and secondary products (volatile compounds) generally appear after the 15th day [17]. In this way, just after fabrication, PPI we used in the present study 
already contained all the volatile compounds resulting from lipid oxidation, originating from the harvest, the fabrication of PPI and the first months of storage. The first substrates, the lipids, generated the profile in volatile compounds of the product, by enzymatic and non-enzymatic oxidations. $A_{W}$ changes during the storage could also impact the oxidation sensitivity. Scheme 1 presents the different phenomena affecting PPI.

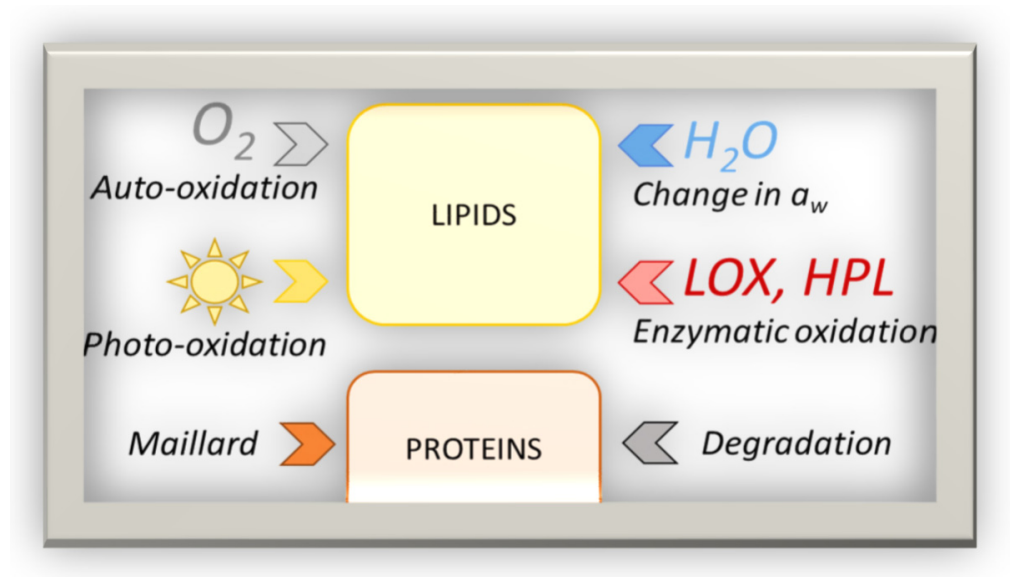

Scheme 1. Reactions involved during the ageing [16,18-20].

Optimal storage conditions are required to limit the off-flavor worsening and the product deterioration. Some studies have already dealt with the evolution of volatile compounds (responsible for the 'beany' off-flavor) during the storage [21,22]. As an example, Schindler et al. (2011) analyzed the impact of transformation processes on the preservation of PPI under good storage conditions, and Azarnia et al. (2011) the impact of the storage temperature on different cultivars of raw peas. The present paper comes as a complementary study, by focusing on the impact of two important parameters of storage on a PPI: light and temperature.

This paper investigated the evolution of volatile compounds, of the odor, and of color of PPI during two storage treatments. The aim was to link the evolution of the volatile compounds with the odor deterioration and to observe the impact of storage parameters. The change of color of the PPI was also investigated as an external indicator of the conservation of the product. The storage conditions selection was guided towards abnormal storage conditions where environmental parameters were poorly controlled. Thus, treatment A was selected, with the product stored at $20{ }^{\circ} \mathrm{C}$ [22] and exposed to ambient light, mimicking a lack of control on the light exposition. Secondly, treatment B was selected, with the product stored at $30{ }^{\circ} \mathrm{C}$ in the dark, mimicking control over the light exposition but a lack of control over the temperature (increase in the storage temperature).

Firstly, the evolution of the volatile compounds, of the odor, and of color during the two storage treatments, were investigated. Then, hypotheses on the mechanisms involved in this evolution were proposed. Nine volatile compounds of interest were subsequently semi-quantified in the PPI. Hexanal, nonanal, 2-nonenal, 3-methylbutanal, 1-octen-3-ol, 3-octen-2-one, 2-pentylfuran, benzaldehyde, and 2,5-dimethylpyrazine were selected due to their reported involvement in the 'beany' off-flavor $[7,10,23,24]$. Finally, a way of predicting the odor using the evolution of the volatile compounds was considered to improve the use of instrumental data for early detection of the off-flavor evolution.

\section{Results and Discussion}

\subsection{Color Evolution}

The evolution of the color parameters $\left(\mathrm{L}^{*}, \mathrm{a}^{*}, \mathrm{~b}^{*}\right)$, during the two storage conditions and over twelve months was presented in Table 1 . The treatment B ( $30^{\circ} \mathrm{C}-$ Dark) had a small impact on the color. At six months, the sample became slightly darker ( $\mathrm{L}^{*}$ diminution) and, after three months, a little bit more red ( $\mathrm{a}^{*}$ increase) and less yellow ( $\mathrm{b}^{*}$ diminution). 
The storage in the dark at $30^{\circ} \mathrm{C}$ was slightly affecting the sample color. The temperature increase enhanced Maillard reactions, leading to a color development and the sample browning [25]. On the other hand, treatment A $\left(20^{\circ} \mathrm{C}\right.$ - Light) was leading to a drastic color change. From three to nine months, the sample became lighter ( $L^{*}$ increase), less red ( $a^{*}$ diminution); and from three to six months, less yellow ( $\mathrm{b}^{*}$ diminution). The sample color was strongly impacted by the exposition to light, as it can be seen with the $\Delta \mathrm{E}^{*}$ presented in the bottom of Table 1. $\Delta \mathrm{E}^{*}$ indicates the color difference between the color at the different treatment times and the original color at $\mathrm{t} 0$. The observed phenomenon could be explained by the carotenoids degradation caused by the light, leading to the product whitening [26]. The color measurement can then be a marker of an abnormal storage, where the product was exposed to light.

Table 1. Color evolution during the ageing ( $n=5$ points in triplicates).

\begin{tabular}{|c|c|c|c|c|c|}
\hline Months & 0 & 3 & 6 & 9 & 12 \\
\hline \multicolumn{6}{|c|}{ Treatment $\mathrm{A}-20^{\circ} \mathrm{C}$ Light } \\
\hline$L^{*}$ & $82.9 \pm 0.2^{d}$ & $87.0 \pm 0.3^{c}$ & $88.2 \pm 0.5^{b}$ & $88.9 \pm 0.2^{\mathrm{a}}$ & $88.8 \pm 0.2^{\mathrm{a}, \mathrm{b}}$ \\
\hline$a^{*}$ & $3.14 \pm 0.06^{\mathrm{a}}$ & $2.3 \pm 0.2^{b}$ & $1.9 \pm 0.3^{c}$ & $1.37 \pm 0.03^{\mathrm{d}}$ & $1.50 \pm 0.05^{\mathrm{d}}$ \\
\hline$b^{*}$ & $20.84 \pm 0.08^{\mathrm{a}}$ & $11.1 \pm 0.4^{\mathrm{b}}$ & $10.6 \pm 0.5^{c}$ & $10.4 \pm 0.1^{\mathrm{c}}$ & $10.7 \pm 0.2^{b c}$ \\
\hline \multicolumn{6}{|c|}{ Treatment B-309 ${ }^{\circ} \mathrm{C}$ Dark } \\
\hline $\mathrm{L}^{*}$ & $83.1 \pm 0.2^{a}$ & $82.7 \pm 0.3^{\mathrm{a}, \mathrm{b}}$ & $82.1 \pm 0.1^{\mathrm{c}}$ & $82.4 \pm 0.2^{b, c}$ & $82.5 \pm 0.3^{\mathrm{b}, \mathrm{c}}$ \\
\hline$a^{*}$ & $3.21 \pm 0.06^{c}$ & $3.39 \pm 0.05^{b}$ & $3.62 \pm 0.06^{\mathrm{a}}$ & $3.66 \pm 0.05^{\mathrm{a}}$ & $3.62 \pm 0.06^{\mathrm{a}}$ \\
\hline$b^{*}$ & $21.21 \pm 0.08^{\mathrm{a}}$ & $20.6 \pm 0.2^{b}$ & $20.8 \pm 0.2^{b}$ & $20.4 \pm 0.2^{\mathrm{b}}$ & $18.8 \pm 0.3^{\mathrm{c}}$ \\
\hline \multicolumn{6}{|c|}{$\Delta \mathrm{E}^{*}$} \\
\hline Treatment A & & 10.6 & 11.6 & 12.2 & 11.8 \\
\hline Treatment B & & 0.8 & 1.2 & 1.2 & 2.5 \\
\hline
\end{tabular}

$\overline{\mathrm{a}-\mathrm{d} \text { : Statistical groups for each parameter on each sample, during time. Different letters mean significant difference }}$ at the 0.05 level.

\subsection{Odor Evolution}

The evolution of the odor during the two storage treatments was presented in Table 2. The evaluation of the odor showed that treatment $\mathrm{B}\left(30^{\circ} \mathrm{C}-\right.$ Dark $)$ did not really affect the odor. The product developed a 'roasted' attribute. This new attribute could be attributed to the Maillard reaction [27]. Especially, the 'roasted' attribute could arise from the lysine, threonine, and leucine involvement in the Maillard reaction [28]. These amino acids and particularly lysine and leucine were well present in pea protein, as presented in the Appendix A, Table A1. Treatment A ( $20^{\circ} \mathrm{C}$ - Light) led to an odor deterioration as early as three months, with an increase in the 'beany' and 'earthy' attributes, and later on with the development of 'rancid' and 'sulfurous' off-notes. The increase of those attributes could be linked to lipid oxidation [16]. The 'rancid' attribute occurred from a strong increase of these reactions, leading to a quick deterioration of the product [29].

Table 2. Odor evolution during the ageing (evaluation by three experts).

\begin{tabular}{ccc}
\hline & Treatment A $\left(\mathbf{2 0}{ }^{\circ} \mathbf{C}\right.$ - Light $)$ & Treatment B (30 ${ }^{\circ} \mathbf{C}$-Dark $)$ \\
\hline 0 & Light 'beany' & Light 'beany' \\
\hline 3 & Strong, 'beany', sharp, earthy & Light 'beany', roasted \\
\hline 6 & Strong, 'beany' +, sharp, earthy & Light 'beany', roasted \\
\hline 9 & 'Beany' +, sharp, earthy, rancid & Light 'beany', roasted, earthy \\
\hline 12 & 'Beany'+, sharp, earthy, rancid & 'Beany', earthy \\
\hline
\end{tabular}




\subsection{Volatile Compounds Evolution}

\subsubsection{Total Chromatographic Area}

Figure 1 presented the evolution of the profile in volatile compounds in total chromatographic area per gram of sample, sorted by chemical families, during the two ageing treatments. The evolution of the full list of volatile compounds during the ageing can be found in Appendix A, Table A2, with the sorting of compounds into the different chemical families.

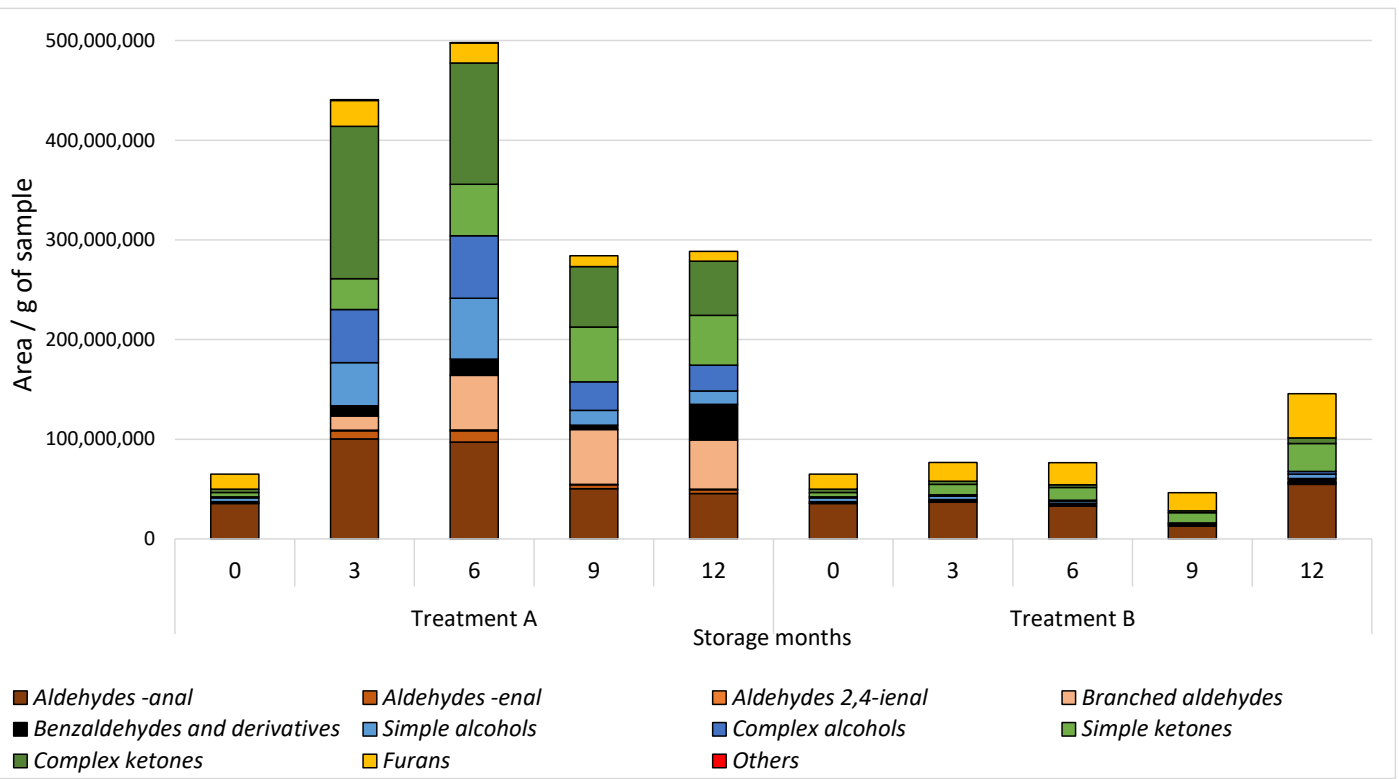

Figure 1. Profile of volatile compounds by chemical family during the ageing $(n=3)$. Treatment A: $20^{\circ} \mathrm{C}$-Light, Treatment B: $30{ }^{\circ} \mathrm{C}$-Dark.

Treatment B ( $30^{\circ} \mathrm{C}$-Dark) had a slight impact on the volatile compounds, with mainly an increase at 12 months [13], correlated with a slight odor change. Lipid oxidation was not amplified. An increase in aldehydes and furans could however be observed, which could be attributed to the Maillard reactions amplified by the temperature. Indeed, Maillard reactions led to the formation of benzaldehyde (amino acids degradation from xylose and phenylalanine [18]) and furans [19]. Moreover, the protein degradation phenomenon can be observed, leading to the appearance of new compounds [20]. This phenomenon was slower than lipid oxidation, as it needed the amino acids and peptide release after proteolysis. Consequently, 3-methylbutanal, a compound resulting from the protein degradation [2], was detected at 12 months.

Treatment A ( $20^{\circ} \mathrm{C}$ - Light) had a strong impact on the volatile compounds. A high increase in the total of volatile compounds can be observed from zero to six months, followed by a small decrease at 9 months and an equilibrium at 12 months. This increase in the amount of volatile compounds was linked to the odor deterioration. An increase in the amount and diversity of aldehydes, alcohols and ketones could be observed, with the development of new compounds. In treatment $A$, the photo-oxidation due to light was added to the other phenomena, playing a crucial role in the formation of volatile compounds. From zero to three months, the highest increase in all types of volatile compounds, especially ketones and aldehydes, could be observed. This strong increase was mainly due to the formation of new compounds, derived from substrates still available. An increase in the furans diversity was also observed: new furans were formed, likely from the photo-oxidation of carotenoids [19]. The amount of volatile compounds increased, then slowed down between three and six months, and decreased at nine months. In order to explain this observation, the total amount of volatile compounds was compared to the number of different volatile compounds in Figure 2. According to these results, 
the lowering of the amount of volatile compounds at nine months was mainly due to the diminution of each volatile compound and did not result from the diminution of the diversity in compounds. As the literature generally focus on the early detection and the early stages of lipid oxidation [30], no precise phenomenon could be identified for this lowering. Volatile compounds can be followed to investigate ripening in fruits or food spoilage for example [31] with appearance of new targeted compounds. However, the volatile compounds fate and transformations over time are not well known. Some hypotheses can be suggested to explain the lowering in the amount of volatile compounds, like the transformation of the volatile compounds in other compounds, for instance nonvolatile compounds. Other phenomena could also be involved. For example, reactions between the compounds themselves, reactions between compounds and the food matrix as it evolves during the storage, or a retention of the compounds by the packaging. Finally, between 9 and 12 months, for treatment $\mathrm{A}\left(20^{\circ} \mathrm{C}\right.$ - Light), the counts of volatile compounds were stable; the product reached an equilibrium.

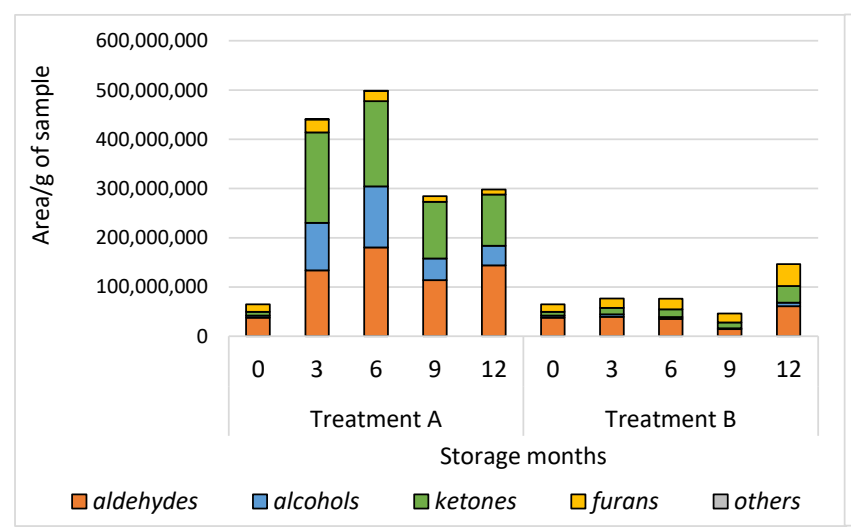

(a)

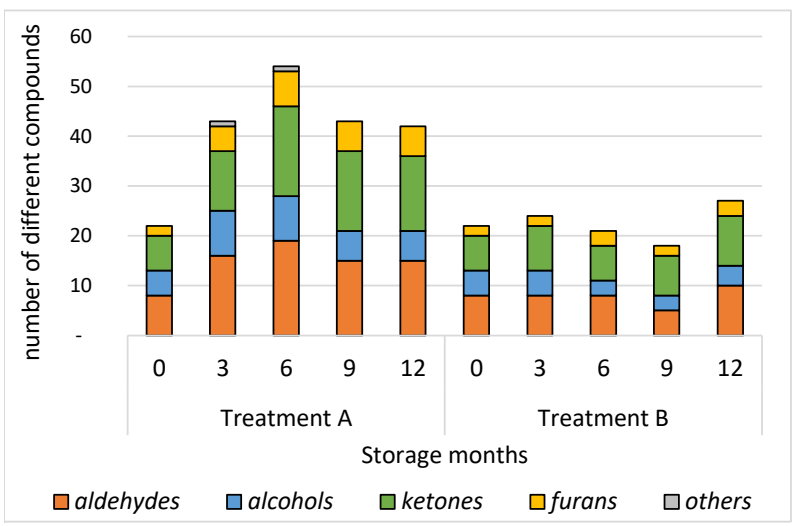

(b)

Figure 2. (a) Evolution of the total amount of volatile compounds during the ageing $(n=3)$; (b) Evolution of the number of different volatile compounds during the ageing $(n=3)$. Treatment A: $20^{\circ} \mathrm{C}$-Light, Treatment B: $30^{\circ} \mathrm{C}$-Dark.

In conclusion, within the range of temperatures studied, corresponding to usual storage conditions, light had a higher impact than temperature on the volatile compounds of the product.

\subsubsection{Semi-Quantification of Compounds of Interest}

Nine interesting compounds involved in the 'beany' off-flavor were studied more in depth and were semi-quantified in the samples. These compounds were: hexanal, nonanal, 2-nonenal, 3-methylbutanal, benzaldehyde, 1-octen-3-ol, 3-octen-2-one, 2-pentylfuran, and 2,5-dimethylpyrazine. The evolution of these compounds during the two ageing conditions was presented in Table 3.

During treatment $\mathrm{B}\left(30^{\circ} \mathrm{C}\right.$-Dark), as observed with the total chromatographic area, volatile compounds were slightly impacted. The amount of 3-octen-2-one, benzaldehyde and 2-pentylfuran increased at 3 or 6 months and the amount of 1-octen-3-ol, 3methylbutanal and hexanal at 12 months. For all compounds, except nonanal, the highest increase for the amount of each compound could be observed at 12 months. The amount of nonanal was the only one to diminish during the ageing. 2-nonenal and 2,5-dimethylpyrazine were not detected during treatment $\mathrm{B}\left(30^{\circ} \mathrm{C}\right.$-Dark). Treatment A ( $20{ }^{\circ} \mathrm{C}$-Light) led to a higher increase in concentration in the studied volatile compounds. The amount of hexanal, nonanal, and 1-octen-3-ol increased at 3 and 6 months, followed by a diminution at 9 months, and a stabilization at 12 months. The amount of 3-octen-2-one followed the same evolution but the diminution started at six months. 
The amount of benzaldehyde strongly increased at 12 months and 2-nonenal appeared at 6 months. 2,5-dimethylpyrazine and 3-methylbutanal were not detected during treatment A $\left(20^{\circ} \mathrm{C}\right.$ - Light $)$.

Table 3. Evolution of the nine compounds of interest during the ageing, in $\mu \mathrm{g}$ of compound/g of sample $(n=3)$.

\begin{tabular}{|c|c|c|c|c|c|}
\hline Months & $\mathbf{0}$ & 3 & 6 & 9 & 12 \\
\hline \multicolumn{6}{|c|}{ Treatment A $\left(20^{\circ} \mathrm{C}-\right.$ Light $)$} \\
\hline Hexanal & $5.1 \pm 0.2^{c}$ & $10.7 \pm 0.3^{a}$ & $10.1 \pm 0.1^{b}$ & $4.1 \pm 0.2^{\mathrm{d}}$ & $3.7 \pm 0.1^{\mathrm{d}}$ \\
\hline Nonanal & $1.01 \pm 0.08^{c}$ & $3.1 \pm 0.3^{a, b}$ & $3.8 \pm 0.5^{a}$ & $2.5 \pm 0.4^{b}$ & $2.3 \pm 0.5^{b}$ \\
\hline 2-nonenal & n.d. & n.d & 0.72 & $0.66 \pm 0.07$ & $0.58 \pm 0.06$ \\
\hline 3-methylbutanal & n.d. & n.d. & n.d. & n.d. & n.d. \\
\hline 1-octen-3-ol & $0.07 \pm 0.01^{\mathrm{d}}$ & $4.64 \pm 0.07^{\mathrm{b}}$ & $5.0 \pm 0.1^{\mathrm{a}}$ & $2.3 \pm 0.1^{\mathrm{c}}$ & $2.04 \pm 0.06^{\mathrm{c}}$ \\
\hline 3-octen-2-one & $0.08 \pm 0.05^{\mathrm{d}}$ & $24.5 \pm 0.5^{\mathrm{a}}$ & $18.1 \pm 0.6^{b}$ & $7.1 \pm 0.2^{c}$ & $6.6 \pm 0.3^{c}$ \\
\hline 2-pentylfuran & $8.1 \pm 0.8^{a}$ & $5.2 \pm 0.4^{b}$ & $5.6 \pm 0.8^{b}$ & $2.05 \pm 0.07^{\mathrm{c}}$ & $1.9 \pm 0.1^{\mathrm{c}}$ \\
\hline Benzaldehyde & $0.41 \pm 0.03^{b}$ & $2.9 \pm 0.2^{b}$ & $5 \pm 1^{b}$ & 3.80 & $10 \pm 4^{a}$ \\
\hline 2,5-dimethylpyrazine & n.d. & n.d. & n.d. & n.d. & n.d. \\
\hline \multicolumn{6}{|c|}{ Treatment B $\left(30^{\circ} \mathrm{C}\right.$-Dark $)$} \\
\hline Hexanal & $5.1 \pm 0.2^{b}$ & $5.5 \pm 0.3^{b}$ & $5.1 \pm 0.3^{b}$ & $1.68 \pm 0.06^{c}$ & $9.3 \pm 0.8^{a}$ \\
\hline Nonanal & $1.01 \pm 0.08^{a}$ & $0.84 \pm 0.08^{a}$ & $0.56 \pm 0.01^{b}$ & $0.31 \pm 0.03^{c}$ & $0.9 \pm 0.1^{\mathrm{a}}$ \\
\hline 2-nonenal & n.d. & n.d. & n.d. & n.d. & n.d. \\
\hline 3-methylbutanal & n.d. & n.d. & n.d. & n.d. & $<0.05$ \\
\hline 1-octen-3-ol & $0.07 \pm 0.01^{b, c}$ & $0.10 \pm 0.01^{b}$ & $0.088 \pm 0.004^{b}$ & $0.05 \pm 0.01^{c}$ & $0.24 \pm 0.02^{a}$ \\
\hline 3-octen-2-one & 0.08 & $0.08 \pm 0.02^{c}$ & $0.20 \pm 0.01^{b}$ & $0.13 \pm 0.01^{c}$ & $0.53 \pm 0.03^{a}$ \\
\hline 2-pentylfuran & $8.1 \pm 0.8^{c}$ & $10 \pm 1^{b c}$ & $11.1 \pm 0.7^{b}$ & $9.5 \pm 0.5^{b, c}$ & $22 \pm 1^{a}$ \\
\hline Benzaldehyde & $0.41 \pm 0.03^{c}$ & $0.48 \pm 0.03^{b, c}$ & $0.55 \pm 0.02^{b}$ & $0.46 \pm 0.03^{b, c}$ & $1.12 \pm 0.06^{\mathrm{a}}$ \\
\hline 2,5-dimethylpyrazine & n.d. & n.d. & n.d. & n.d. & n.d. \\
\hline
\end{tabular}

This semi-quantification step allowed confirming the observations made previously with the total chromatographic area. For example, 3-methylbutanal was detected only at 12 months in treatment $\mathrm{B}\left(30^{\circ} \mathrm{C}\right.$-Dark) and the amount of aldehydes strongly increased during the first months of treatment $\mathrm{A}\left(20^{\circ} \mathrm{C}\right.$ - Light). The amounts of volatile compounds found during treatment $\mathrm{A}\left(20^{\circ} \mathrm{C}\right.$ - Light $)$ were very high. For example, the hexanal amount obtained at 3 months in treatment $A$ was not obtained before 12 months using treatment $B$.

\subsection{Correlation between Instrumental Data and Odor}

The odor evolution of the PPI seemed to be linked to the instrumental data of the volatile compounds. For example, the odor deterioration at three months in treatment A $\left(20^{\circ} \mathrm{C}\right.$ - Light) matched with the increase of the amount of volatile compounds. The results used for Figure 1 were processed differently in order to investigate if instrumental data could predict the odor evolution. For all the volatile compounds identified in the product, the sensory descriptors were looked up [32] and the compounds were classified into different attribute families such as 'green' or 'earthy' as presented in Appendix A, Table A3. As the 'beany' off-flavor was investigated here, a focus was made on its different attributes, like the different types of 'green'. A given descriptor was then represented as 

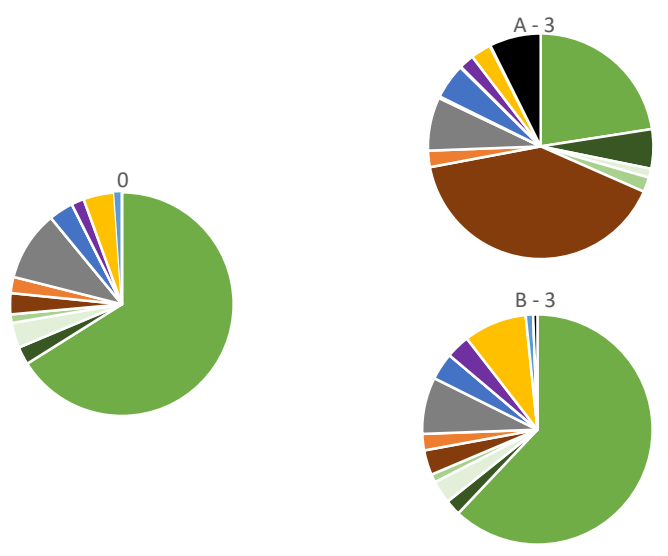

green

- earthy

- fermented

solvent - ethereal - alcoholic - metallic

- fatty - green
bitter almond
sulfurous
- Undefined

the ratio of the percentage of the cumulative amount of the different volatile compounds responsible for the descriptor, to the total amount of all volatile compounds. The evolution of these different sensory attributes during the two ageing conditions were presented in Figure 3.
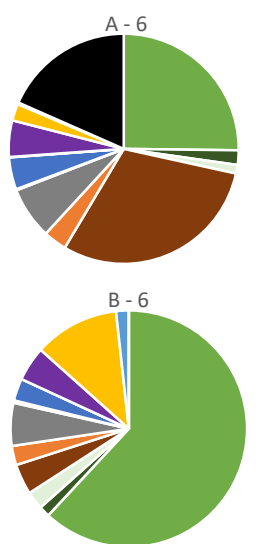

herbal - green

- aldehydic

- fruity - floral
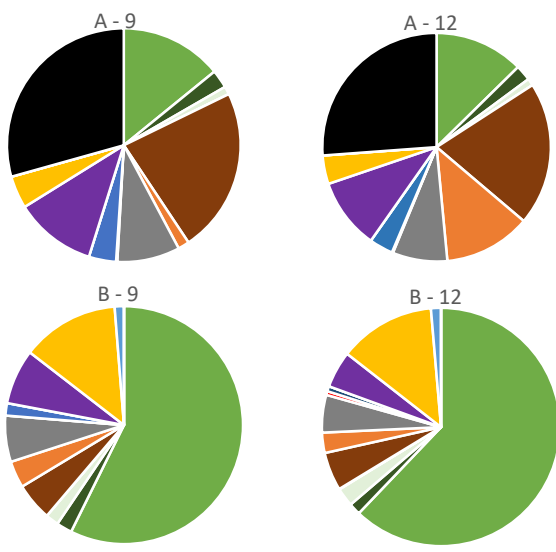

other - green

- Chocolate - roasted

pungent - cheesy

Figure 3. Profile in ratios of volatile compounds sorted by sensory descriptors during the two ageing conditions $(n=3)$. A given descriptor was represented as the ratio of the percentage of the cumulative amount of the volatile compounds responsible for the descriptor to the total amount of all volatile compounds. Treatment A: $20^{\circ} \mathrm{C}$ - Light, Treatment B: $30^{\circ} \mathrm{C}$-Dark.

During treatment $\mathrm{B}\left(30^{\circ} \mathrm{C}-\right.$ Dark $)$, the profile of volatile compounds sorted by sensory descriptor was slightly evolving. Compounds responsible for the 'pungent-cheesy' attribute increased. During treatment A $\left(20^{\circ} \mathrm{C}\right.$ - Light), compounds responsible for the 'herbalgreen' attribute decreased and compounds responsible for 'fatty-green', 'earthy', 'bitter almond', and 'fruity-floral' attributes increased.

With this representation, it was possible to see a link between the instrumental data and the odor. At three months in treatment A $\left(20^{\circ} \mathrm{C}\right.$-Light), an 'earthy' off-flavor was perceived, as presented in Table 1, and this was linked to an increase in the proportion of volatile compounds responsible for 'earthy' notes presented in Figure 3. In the same way, for three and six months in treatment $\mathrm{B}\left(30^{\circ} \mathrm{C}\right.$-Dark), little or no changes in the odor were smelled, and no big changes were seen in the ratios of volatile compounds. With the representation used in Figure 3 (volatile compounds sorted by sensory descriptors), changes in the ratios of the different descriptors were linked to the perception of new sensory attributes. Following these changes could help for the early detection of new off-flavors in a product.

However, there was a limit to these conclusions. This representation (Figure 3) was not sufficient to describe the global sensory profile of a product and this might not work with all attributes. For example, the increase in the proportion of compounds related to 'fruity' or 'floral' notes in treatment $\mathrm{A}\left(20^{\circ} \mathrm{C}\right.$ - Light) at 9 months was not perceived during the odor evaluation. To explain these phenomena, instrumental data needed to be checked together with information about the volatile compounds, like their perception threshold, their intensity and their interaction type with other types of compounds. Due to their very low perception threshold and high odor intensity [6,7], 'beany' and 'rancid' volatile compounds might conceal the sensory aspects of 'fruity' and 'floral' compounds. Moreover, with a 'destructive' sensory interaction between 'beany' /'rancid' and 'fruity' /'floral' compounds, one sensory aspect might completely erase the other one [33]. 


\section{Materials and Methods}

\subsection{Sample}

A spray-dried pea protein isolate (85\% protein dry matter, composed mainly of globulins) was supplied by Roquette Frères S.A.

\subsection{Ageing of the Samples}

Approximately $20 \mathrm{~g}$ of the PPI were placed flat in plastic bags and exposed to the two storage treatments for 12 months: treatment $\mathrm{A}-20^{\circ} \mathrm{C}$ exposed to light, and treatment $\mathrm{B}-30^{\circ} \mathrm{C}$ in the dark. The PPI was sampled at $0,3,6,9$, and 12 months. At each sampling time, $2 \mathrm{~g}$ of sample was placed in a clear storage glass vial, and the different analyses were conducted directly after sampling.

\subsection{Color Measurement}

The color of the samples was determined with a Chromatometer CR-400 Konica Minolta. Three color parameters, $L^{*}$ (lightness), $a^{*}$ (redness) and $b^{*}$ (yellowness) were measured. The analysis was conducted directly on the samples in the plastic bags before sampling, with five measuring points flashed in triplicates. $\Delta \mathrm{E}^{*}$, the color difference between the color at the different treatment times and the original color at $t 0$, was calculated as follows with Equation (1).

$$
\begin{gathered}
\Delta \mathrm{E}^{*}=\sqrt{\left.\left.\left(\mathrm{L}^{*}{ }_{2}-\mathrm{L}^{*}\right)_{1}\right)^{2}+\left(\mathrm{a}^{*}{ }_{2}-\mathrm{a}^{*}\right)^{2}+\left(\mathrm{b}^{*}{ }_{2}-\mathrm{b}^{*}\right)_{1}\right)^{2}} \\
\mathrm{~L}^{*}{ }_{1}, \mathrm{a}^{*}{ }_{1}, \mathrm{~b}^{*}{ }_{1}: \text { original color parameters at } \mathrm{t} 0 \\
\mathrm{~L}^{*}{ }_{2}, \mathrm{a}^{*}{ }_{2}, \mathrm{~b}_{2}^{*}: \text { color parameters during the treatments }
\end{gathered}
$$

\subsection{Odor Determination}

The odor was determined by direct sniffing of the product in the storage glass vial. At least $24 \mathrm{~h}$ after sampling, the products were smelled into the glass vial by three experts, directly at the opening of the vial. The odor character and intensity were descripted and the enounced sensory descriptors of the sample were recorded [34]. Especially, the products were evaluated toward the 'beany', 'earthy', and 'rancid' attributes. The 'beany' attribute was separated in three categories: light 'beany' when the attribute was slightly present; 'beany' when the attribute was well present and 'beany' + when the attribute was predominant or had a high intensity. The adjective 'strong' was used to indicate that the odor of the product was globally more intense.

\subsection{Volatile Compounds Analysis}

The volatile compounds extraction was done using headspace solid micro-extraction and the analysis using gas chromatography coupled with mass spectrophotometry (HSSPME-GC-MS). For each treatment at each sampling time, volatile compounds analysis was run in triplicates, using a previously optimized method for PPI [35].

From the $2 \mathrm{~g}$ aliquot, a $0.2 \mathrm{~g}$ PPI sample was weighted directly in a new clear $20 \mathrm{~mL}$ extraction vial (VA201) capped with septum caps (18 mm caps, $8 \mathrm{~mm}$ PTFE/ silicon septum, SACA001), all purchased from JASCO, France. Distilled water was added to obtain a $2 \mathrm{~mL}$ suspension at $10 \%(w / v)$ and a liquid/gas ratio of $2 / 18(v / v)$. A SPME device containing a $1 \mathrm{~cm}$ fused-silica fiber coated with a 50/30 $\mu \mathrm{m}$ thickness of DVB/CAR/PDMS (divinylbenzene/carboxen/polydimethylsiloxane) was used for HS-SPME extraction. This fiber was selected to ensure the best extraction of a diversity of volatile compounds [9,10,36-38]. The fiber (24 Ga 50/30 $\mu \mathrm{m}$, for manual holder, 3 pK, 57328-U) was purchased from Sigma and used with a manual fiber holder. The extractions were carried out in an electro thermal magnetic stirrer with a water bath (MS-H-Pro+, DLAB) to ensure a homogeneous temperature and constant agitation for the sample and headspace. The fiber was conditioned before analysis by heating it in the gas chromatograph injection port at $270{ }^{\circ} \mathrm{C}$ for $30 \mathrm{~min}$, according to the manufacturer's specifications. Equilibrium step and extraction step were conducted both at $40{ }^{\circ} \mathrm{C}$ with agitation at $350 \mathrm{rpm}$ in the dark. The equilibrium time was 
$30 \mathrm{~min}$ and the extraction time, exposure of the fiber in the headspace of the vial was $60 \min [9,10,13,36-43]$.

An HP 6890 Series Gas Chromatograph (Hewlett-Packard, Palo Alto, CA, USA) equipped with an HP 5973 Mass Selective Detector (Agilent Technologies, Palo Alto, CA, USA) (Quadrupole) was used with a DB-WAX column $(30 \mathrm{~m} \times 0.32 \mathrm{~mm} \times 0.25 \mu \mathrm{m}$, 123-7032, Agilent, J\&W Scientific, Santa Clara, United States) to analyze the compounds of interest $[10,13,21,23]$. The SPME fiber was desorbed and maintained in the injection port at $250{ }^{\circ} \mathrm{C}$ for $5 \mathrm{~min}$. The sample was injected in split mode, with a purge flow of $140 \mathrm{~mL} / \mathrm{min}$ at 0 min to generate sharp, well-separated peaks on the chromatograph. Helium was used as a carrier gas at $1.4 \mathrm{~mL} / \mathrm{min}$ with a linear velocity of $43 \mathrm{~cm} / \mathrm{s}$. The programmed temperature, selected from preliminary trials, was isothermal at $40^{\circ} \mathrm{C}$ for $3 \mathrm{~min}$, raised to $100{ }^{\circ} \mathrm{C}$ at a rate of $3{ }^{\circ} \mathrm{C} / \mathrm{min}$, and then raised to $230{ }^{\circ} \mathrm{C}$ at a rate of $5^{\circ} \mathrm{C} / \mathrm{min}$ and held for $10 \mathrm{~min}$. The total run time was $59 \mathrm{~min}[13,21]$. The ionization source and transfer line temperatures were set respectively at $230^{\circ} \mathrm{C}$ and $190^{\circ} \mathrm{C}$.

The mass spectra were obtained using a mass selective detector with an electron impact voltage of $70 \mathrm{eV}$ in full scan mode over the range $m / z 29$ to 400 . Compounds were identified by comparing their mass spectra with NIST 08 (National Institute of Standards and Technology), Wiley, and INRA libraries, with a low integration limit of 50,000 in peak area, allowing the best peak identification.

\subsection{Semi-Quantification}

Nine compounds of interest were semi-quantified in the PPI, due to their involvement in the 'beany' off-flavor $[7,10,23,24]$. The following standards were purchased from Sigma-Aldrich: hexanal (98\% purity, CAS 66-25-1), nonanal (>98\%, CAS 124-19-6), trans-2nonenal (97\%, CAS 18829-56-6), 3-methylbutanal (97\%, CAS 590-86-3), 1-octen-3-ol (98\%, CAS 3391-86-4), 3-octen-2-one (98\%, CAS 1669-44-9), 2-pentylfuran (98\%, CAS 3777-69-3), benzaldehyde (99\%, CAS 100-52-7), and 2,5-dimethylpyrazine (98\%, CAS 123-32-0). An external calibration method, previously optimized for PPI [35], was used. The calibration curves of each of the nine compounds were obtained for concentrations ranging from 0.001 to $2.5 \mathrm{ppm}$, in distilled water. The amount of each compound in the sample was calculated as in the following example with hexanal. Semi-quantification steps were as following, with $\mathrm{a}$ and $\mathrm{b}$ from the calibration curve of hexanal $(\mathrm{a}=$ slope, $\mathrm{b}=$ intercept of the regression):

$$
\text { Area Hexanal }=11585856 \text { A.U. }
$$

$$
\begin{aligned}
{[\text { Hexanal }]_{\text {in the assay }}(\mu \mathrm{g} / \mathrm{mL})=(\text { Area hexanal }-\mathrm{b}) / \mathrm{a}=(11585856-157037) / 1 \times 10^{7}=1.14 \mu \mathrm{g} / \mathrm{mL} } \\
\begin{aligned}
{[\text { Hexanal }]_{\text {in the sample }}(\mu \mathrm{g} / \mathrm{g}) } & =\left([\text { Hexanal }]_{\text {in the assay }}(\mu \mathrm{g} / \mathrm{mL}) \times \mathrm{V}_{\text {solution }}(\mathrm{mL})\right) / \mathrm{m}_{\text {sample }}(\mathrm{g}) \\
& =(1.14 \times 2) / 0.2078=11.0 \mu \mathrm{g} / \mathrm{g} \\
& \mathrm{m}_{[\text {Hexanal }] \text { in the sample }}(n=3)=10.7 \pm 0.3 \mu \mathrm{g} \text { of hexanal } / \mathrm{g} \text { of PPI }
\end{aligned}
\end{aligned}
$$

\subsection{Data Treatment}

The statistical treatment of color data and semi-quantification data was performed using the software Minitab 18 (Minitab, LLC., State College, Pennsylvania, United States). One-way analysis of variance (ANOVA) was applied for all the results after validating the feasibility of the test using variance analysis. Significance was established at $p<0.05$. ANOVA showing significant differences lead to the use of Tukey's multiple comparison test to group the samples.

Volatile compounds were first sorted by chemical family to obtain Figure 1. To obtain Figure 3, volatile compounds were sorted by sensory descriptor [32] as presented in Appendix A, Table A3. A given descriptor was then represented as the ratio of the percentage of the cumulative amount of the different volatile compounds responsible for the descriptor, to the total amount of all volatile compounds. 


\section{Conclusions}

To conclude, the storage conditions had a strong impact on the volatile compounds, on the odor, and on the color of the studied PPI. This work highlighted the importance of light exposition and the crucial role of the first three months of storage. Indeed, light exposition was detrimental to the color and the odor of PPI, and a high increase in the total amount of volatile compounds was observed.

Conservation of PPI or other pulses proteins must be achieved in the dark of with light impermeable packaging to prevent the light exposition. This work also highlighted the fate of volatile compounds in long-term ageing: past six months, the amount of volatile compounds started to decrease to reach an equilibrium. In association with the volatile compounds, the evolution of the color could be a good indicator to follow, to detect an abnormal evolution of the product. The amino acid, fatty acid, and hydrolysis state of the product are important factors that may also affect the evolution of the product during the storage.

When representing analytical data using sensory descriptors, it was possible to predict how compounds responsible for different attributes evolved. This could be used for early detection of an odor change, by detecting a change in the ratios of compounds responsible for the different studied attributes.

With the increasing use of vegetable proteins in food products, their storage conditions and conservation over time must be carefully studied and established, as small variations could potentially lead to detrimental sensory impacts. Environmental parameters should be controlled to optimize conservation, especially with intermediate products such as PPI that are highly sensible to oxidation. These recommendations could however be advised also for the storage of raw materials such as raw peas, or final products containing PPI.

Author Contributions: Conceptualization, E.F., Methodology, E.F. and N.C., Validation, E.F. and N.C., Investigation, E.F., Writing-original draft, E.F., Writing—review and editing, N.C. and R.C., Supervision, N.C. and R.C. All authors have read and agreed to the published version of the manuscript.

Funding: This research was funded by the Regional Council of Bourgogne-Franche Comté, the European Regional Development Fund (ERDF), and a grant from Roquette Frères S.A.

Institutional Review Board Statement: Not applicable.

Informed Consent Statement: Not applicable.

Data Availability Statement: Not applicable.

Conflicts of Interest: The authors declare no conflict of interest.

Sample Availability: Samples are not available from the authors.

\section{Appendix A Complementary Data}

Table A1. Amino-acid composition of pea protein, g of amino acid/100 g of protein [44].

\begin{tabular}{ccccccccccccccccccc}
\hline Amino Acids & Iso & Leu & Lys & Met & Phe & Thr & Trp & Val & Arg & His & Ala & Asp & Cys & Glu & Gly & Pro & Ser & Tyr \\
\hline Pea & 3.3 & 6.6 & 6.8 & 1.0 & 4.2 & 3.6 & 0.9 & 3.9 & 6.8 & 2.5 & 4.3 & 10.7 & 1.6 & 16.9 & 4.3 & 3.4 & 4.8 & 3.1 \\
\hline
\end{tabular}


Table A2. Evolution of the volatile compounds during the two treatments, sorted by chemical families, in area/g of sample $(n=3)$.

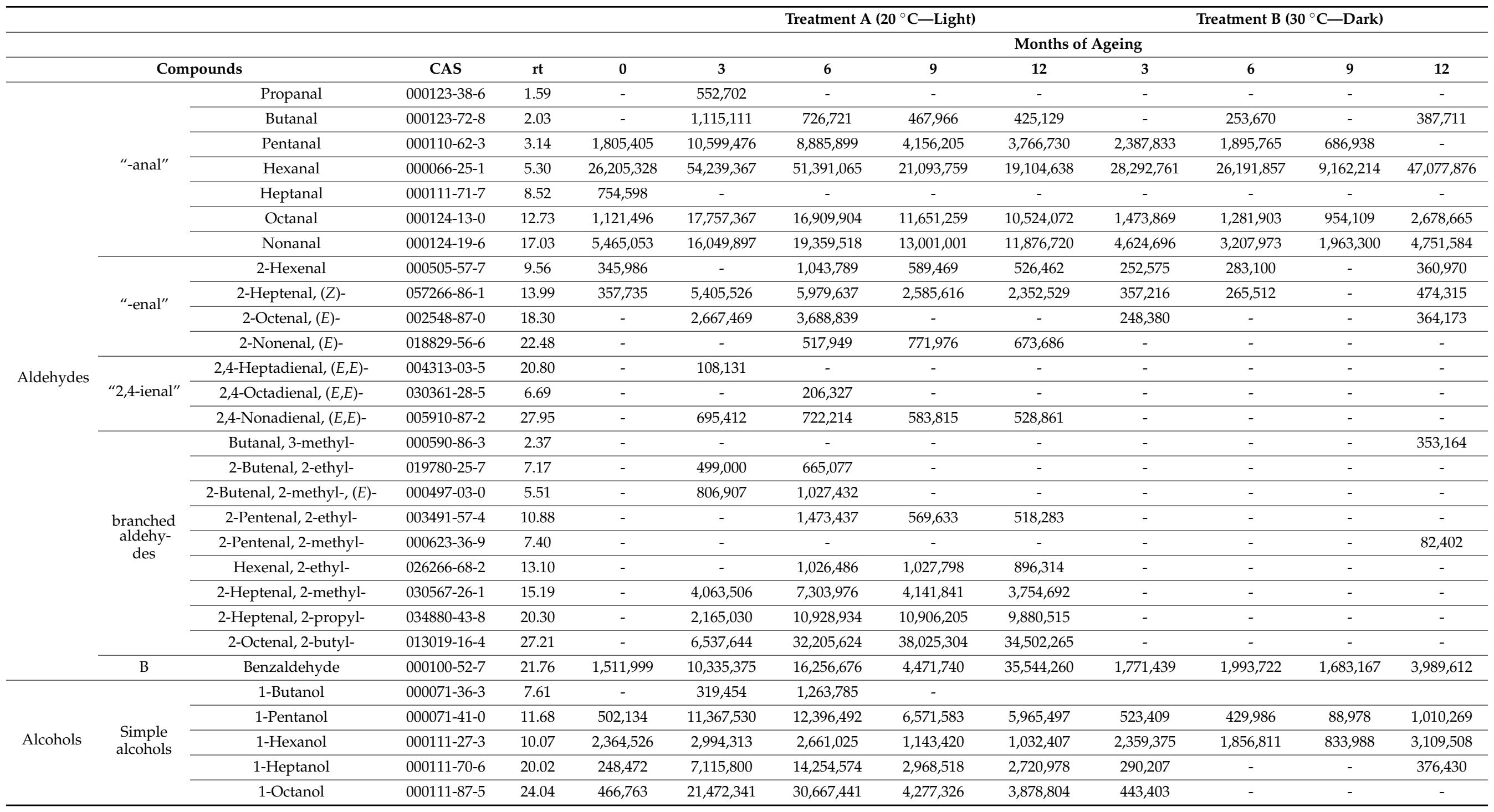


Table A2. Cont.

\begin{tabular}{|c|c|c|c|c|c|c|c|c|c|c|c|c|c|}
\hline & & & & & & \multicolumn{5}{|c|}{ Treatment A $\left(20^{\circ} \mathrm{C}-\right.$ Light $)$} & \multicolumn{3}{|c|}{ Treatment B $\left(30^{\circ} \mathrm{C}\right.$-Dark $)$} \\
\hline & & & & & & & & & Months o & geing & & & \\
\hline \multicolumn{3}{|c|}{ Compounds } & CAS & rt & 0 & 3 & 6 & 9 & 12 & 3 & 6 & 9 & 12 \\
\hline & \multirow{4}{*}{$\begin{array}{l}\text { Complex } \\
\text { alcohols }\end{array}$} & 1-Penten-3-ol & 000616-25-1 & 8.09 & - & 355,276 & 997,392 & - & - & - & - & - & - \\
\hline & & 2-Octen-1-ol, $(E)$ - & 018409-17-1 & 25.80 & - & 544,347 & $9,698,048$ & $5,796,319$ & $5,256,259$ & - & - & - & - \\
\hline & & 1-Nonen-4-ol & 035192-73-5 & 26.38 & - & - & $1,674,594$ & - & - & - & - & - & - \\
\hline & & 2-Nonen-1-ol, $(E)$ - & 031502-14-4 & 25.89 & - & $5,807,586$ & - & - & - & - & - & - & - \\
\hline \multirow{20}{*}{ Ketones } & \multirow{11}{*}{$\begin{array}{l}\text { Simple } \\
\text { ketones }\end{array}$} & Acetone & 000067-64-1 & 1.69 & - & - & 191,413 & - & - & - & - & - & - \\
\hline & & 2-Butanone & $000078-93-3$ & 2.21 & - & - & 400,901 & - & - & - & - & - & 178,098 \\
\hline & & 2-Heptanone & $000110-43-0$ & 8.47 & $2,914,251$ & $12,727,931$ & $11,834,021$ & $12,835,121$ & $11,630,756$ & $6,778,697$ & $8,889,881$ & $6,164,234$ & $19,027,798$ \\
\hline & & 2-Octanone & 000111-13-7 & 12.60 & 363,899 & $4,698,052$ & $7,159,877$ & $4,813,146$ & $4,359,318$ & 645,326 & 758,827 & 705,801 & $1,988,617$ \\
\hline & & 3-Octanone & 000106-68-3 & 11.30 & - & $2,616,637$ & $3,338,368$ & $2,040,859$ & $1,853,790$ & 86,399 & - & - & 553,777 \\
\hline & & 2-Nonanone & 000821-55-6 & 16.87 & 715,439 & $3,902,976$ & $10,344,382$ & $10,462,661$ & $9,479,837$ & $1,590,570$ & $2,187,542$ & $2,034,953$ & $4,795,261$ \\
\hline & & 3-Nonanone & 000925-78-0 & 15.53 & - & 417,012 & 740,060 & - & - & - & - & - & - \\
\hline & & 4-Nonanone & 004485-09-0 & 14.23 & - & - & $2,813,609$ & $1,619,983$ & $1,472,690$ & - & - & - & - \\
\hline & & 2-Decanone & 000693-54-9 & 21.10 & 476,536 & $2,763,256$ & $7,534,404$ & $9,596,606$ & $8,698,039$ & 968,225 & $1,038,001$ & $1,254,108$ & $1,629,600$ \\
\hline & & 2-Undecanone & $000112-12-9$ & 24.94 & - & - & 335,632 & 469,896 & 425,404 & - & - & - & - \\
\hline & & 6-Undecanone & $000927-49-1$ & 22.45 & - & $2,281,893$ & $6,017,331$ & $7,803,108$ & $7,086,946$ & & & & \\
\hline & \multirow{9}{*}{$\begin{array}{l}\text { Complex } \\
\text { ketones }\end{array}$} & 3-Hepten-2-one, 5-methyl- & 005090-16-4 & 14.33 & - & - & $18,668,068$ & $9,738,639$ & $8,833,310$ & - & - & - & - \\
\hline & & 5-hepten-2-one, 6-methyl- & 000110-93-0 & 14.58 & - & - & - & - & - & - & 301,548 & 181,797 & 385,650 \\
\hline & & 3-Cyclohepten-1-one & 001121-64-8 & 2.81 & - & - & $1,304,173$ & - & - & - & - & - & - \\
\hline & & 1-Octen-3-one & $004312-99-6$ & 13.24 & - & $2,143,093$ & $1,628,850$ & 685,187 & 624,964 & - & - & - & - \\
\hline & & 3-Octen-2-one & 001669-44-9 & 17.63 & 609,220 & $124,925,658$ & $90,943,451$ & $36,567,885$ & $32,817,049$ & 686,237 & $1,276,001$ & 932,929 & $2,900,763$ \\
\hline & & 2,3-Octanedione & 000585-25-1 & 14.44 & 796,320 & $9,271,454$ & - & - & - & 889,117 & - & - & - \\
\hline & & 3,5-Octadien-2-one & $038284-27-4$ & 23.86 & $1,695,929$ & $16,505,439$ & $6,034,706$ & $3,770,372$ & $3,375,879$ & $1,439,512$ & $1,148,274$ & 977,159 & $1,988,993$ \\
\hline & & 3-Nonen-2-one & 014309-57-0 & 21.59 & - & - & $2,989,705$ & $7,195,393$ & $6,526,713$ & - & - & - & - \\
\hline & & 3-Decen-2-one & 010519-33-2 & 25.46 & - & - & - & $2,649,693$ & $2,400,948$ & - & - & - & - \\
\hline
\end{tabular}


Table A2. Cont.

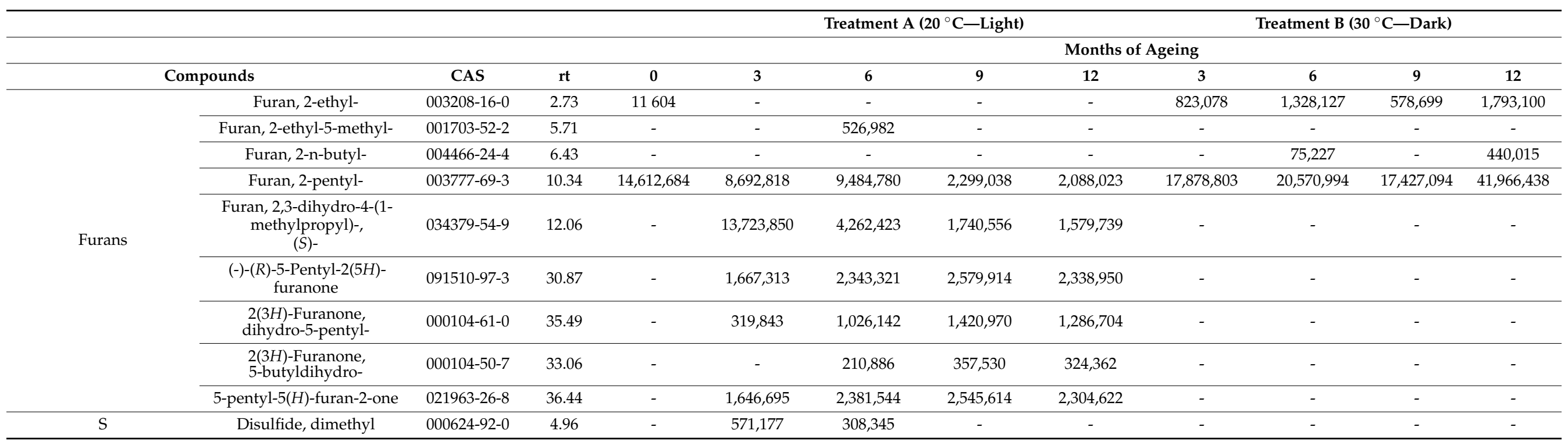

Legend: $\mathrm{rt}=$ retention time in minutes, $\mathrm{S}=$ sulfides, $\mathrm{B}=$ benzaldehyde . 
Table A3. Sorting of volatile compounds by sensory descriptors.

\begin{tabular}{|c|c|c|c|}
\hline Descriptor & Compounds & Descriptor & Compounds \\
\hline \multirow{13}{*}{ Green } & Hexanal & Sulfurous & Disulfide, dimethyl \\
\hline & Heptanal & \multirow{10}{*}{ Fruity-floral } & 2-Nonanone \\
\hline & 2-Hexenal & & 2-Decanone \\
\hline & 2-Heptenal, $(E)$ - & & 5-Hepten-2-one, 6-methyl- \\
\hline & 2,4-Heptadienal, $(E, E)$ - & & 2-n-Butyl furan \\
\hline & 2,4-Nonadienal, $(E, E)-$ & & 3-Nonanone \\
\hline & 1-Heptanol & & $(-)-(R)$-5-Pentyl-2(5H)-furanone \\
\hline & 2-Octen-1-ol, $(E)$ - & & 2(3H)-Furanone, dihydro-5-pentyl- \\
\hline & Furan, 2-pentyl- & & 3-Nonen-2-one \\
\hline & 1-Octanol & & 2-Undecanone \\
\hline & 1-Penten-3-ol & & 2(3H)-Furanone, 5-butyldihydro- \\
\hline & 2-Butenal, 2-methyl-, $(E)$ - & Pungent-cheesy & 2-Heptanone \\
\hline & 2,4-Octadienal, $(E, E)-$ & \multirow{5}{*}{$\begin{array}{l}\text { Solvent-ethereal-alcoholic- } \\
\text { metallic }\end{array}$} & Acetone \\
\hline \multirow{5}{*}{ Fatty-green } & 2-Octenal, $(E)-$ & & 2-Butanone \\
\hline & 2-Nonenal, $(E)$ - et $(Z)$ - & & Furan, 2-ethyl- \\
\hline & 2-Nonen-1-ol, $(E)-$ & & Propanal \\
\hline & 3,5-Octadien-2-one, $(E, E)$ - & & Furan, 2-ethyl-5-methyl- \\
\hline & 3-Decen-2-one & \multirow{14}{*}{ Undefined } & 2-Octenal, 2-butyl- \\
\hline \multirow{2}{*}{ Herbal-green } & 1-Hexanol & & 3-Hepten-2-one, 5-methyl- \\
\hline & 3-Octanone & & 2-Butenal, 2-ethyl- \\
\hline \multirow{2}{*}{ Other-green } & 2,3-Octanedione & & 2-Heptenal, 2-methyl- \\
\hline & 2-pentenal, 2-methyl & & 5-Decanone \\
\hline \multirow{4}{*}{ Earthy } & 1-Octen-3-ol & & 6-Undecanone \\
\hline & 2-Octanone & & Furan, 2,3-dihydro-4-(1-methylpropyl)-, (S)- \\
\hline & 1-Octen-3-one & & 5-pentyl-5(H)-furan-2-one \\
\hline & 3-Octen-2-one, $(E)$ - & & 2-Heptenal, 2-propyl- \\
\hline Bitter almond & Benzaldehyde & & 2-pentenal, 2-ethyl \\
\hline \multirow{2}{*}{ Aldehydic } & Octanal & & Hexenal, 2-ethyl- \\
\hline & Nonanal & & 1-Nonen-4-ol \\
\hline \multirow{2}{*}{ Chocolate-roasted } & Butanal, 3-methyl- & & 3-Cyclohepten-1-one \\
\hline & Butanal & & 4-Nonanone \\
\hline \multirow{3}{*}{ Fermented } & Pentanal & & \\
\hline & 1-Pentanol & & \\
\hline & 1-Butanol & & \\
\hline
\end{tabular}

\section{References}

1. Young, V.R.; Pellett, P.L. Plant proteins in relation to human protein and amino acid nutrition. Am. J. Clin. Nutr. 1994, 59, 1203S-1212S. [CrossRef] [PubMed]

2. Fischer, E.; Cachon, R.; Cayot, N. Pisum sativum vs Glycine max, a comparative review of nutritional, physicochemical, and sensory properties for food uses. Trends Food Sci. Technol. 2020, 95, 196-204. [CrossRef]

3. Bordat, B.; Lemanceau, P.; Jegou, P.; Boidevezi, X. Quel Système Alimentaire Durable Demain ? Illustration Du Projet TIGA de La Métropole. Food Use Tech. Congres. 2018. Available online: https:/ / foodusetech.fr/fr/les-conferences (accessed on 23 November 2021).

4. Bi, S.; Xu, X.; Luo, D.; Lao, F.; Pang, X.; Shen, Q.; Hu, X.; Wu, J. Characterization of Key Aroma Compounds in Raw and Roasted Peas (Pisum sativum L.) by Application of Instrumental and Sensory Techniques. J. Agric. Food Chem. 2020, 68, $2718-2727$. [CrossRef]

5. Trikusuma, M.; Paravisini, L.; Peterson, D.G. Identification of aroma compounds in pea protein UHT beverages. Food Chem. 2020, 312, 126082. [CrossRef] [PubMed]

6. Rackis, J.J.; Sessa, D.J.; Honig, D.H. Flavor problems of vegetable food proteins. J. Am. Oil Chem. Soc. 1979, 56, 262-271. [CrossRef]

7. Vara-Ubol, S.; Chambers, E.; Chambers, D.H. Sensory characteristics of chemical compound potentially associated with beany aroma in foods. J. Sens. Stud. 2004, 19, 15-26. [CrossRef] 
8. Yousseef, M. Compréhension et Analyse Alimentaire D’un Mix Fermenté de Protéines Animales/Protéines Végétales. Influence Sur la Physico-Chimie et L'acceptabilité des Produits Obtenus. Ph.D. Thesis, Université de Bourgogne, Dijon, France, 2017.

9. Azarnia, S.; Boye, J.I.; Warkentin, T.; Malcolmson, L.; Sabik, H.; Bellido, A.S. Volatile flavour profile changes in selected field pea cultivars as affected by crop year and processing. Food Chem. 2011, 124, 326-335. [CrossRef]

10. Murat, C. Etude de la Fraction Volatile D’extraits Protéiques de Pois: Propriétés et Interactions Avec le Milieu. Ph.D. Thesis, University of Burgundy, Dijon, France, 2013.

11. Murray, K.E.; Shipton, J.; Whitfield, F.B.; Kennett, B.H.; Stanley, G. Volatile Flavor Components from Green Peas (Pisum Sativum). 1. Alcohols in Unblanched Frozen Peas. J. Food Sci. 1968, 33, 290-294. [CrossRef]

12. Murray, K.E.; Shipton, J.; Whitfield, F.B.; Last, J.H. The volatiles of off-flavoured unblanched green peas (Pisum sativum). J. Sci. Food Agric. 1976, 27, 1093-1107. [CrossRef]

13. Schindler, S.; Zelena, K.; Krings, U.; Bez, J.; Eisner, P.; Berger, R.G. Improvement of the Aroma of Pea (Pisum sativum) Protein Extracts by Lactic Acid Fermentation. Food Biotechnol. 2012, 26, 58-74. [CrossRef]

14. Angerosa, F.; Alessandro, N.; Basti, C.; Vito, R. Biogeneration of Volatile Compounds in Virgin Olive Oil: Their Evolution in Relation to Malaxation Time. J. Agric. Food Chem. 1998, 46, 2940-2944. [CrossRef]

15. Sandulachi, E. Water Activity Concept and Its Role in Food Preservation. Available online: http://www.utm.md/meridian/2012 /MI_4_2012/8_Art_Sandulachi_E_Water.pdf (accessed on 4 February 2020).

16. Labuza, T.P.; Dugan, L.R. Kinetics of lipid oxidation in foods. CRC Crit. Rev. Food Technol. 1971, 2, 355-405. [CrossRef]

17. Semenova, M.G.; Antipova, A.S.; Zelikina, D.V.; Martirosova, E.I.; Plashchina, I.G.; Palmina, N.P.; Binyukov, V.I.; Bogdanova, N.G.; Kasparov, V.V.; Shumilina, E.A.; et al. Biopolymer nanovehicles for essential polyunsaturated fatty acids: Structure-Functionality relationships. Food Res. Int. 2016, 88, 70-78. [CrossRef] [PubMed]

18. Pripis-Nicolau, L.; de Revel, G.; Bertrand, A.; Maujean, A. Formation of Flavor Components by the Reaction of Amino Acid and Carbonyl Compounds in Mild Conditions. J. Agric. Food Chem. 2000, 48, 3761-3766. [CrossRef]

19. Limacher, A.; Kerler, J.; Davidek, T.; Schmalzried, F.; Blank, I. Formation of Furan and Methylfuran by Maillard-Type Reactions in Model Systems and Food. J. Agric. Food Chem. 2008, 56, 3639-3647. [CrossRef]

20. Marilley, L.; Casey, M.G. Flavours of cheese products: Metabolic pathways, analytical tools and identification of producing strains. Int. J. Food Microbiol. 2004, 90, 139-159. [CrossRef]

21. Schindler, S.; Wittig, M.; Zelena, K.; Krings, U.; Bez, J.; Eisner, P.; Berger, R.G. Lactic fermentation to improve the aroma of protein extracts of sweet lupin (Lupinus angustifolius). Food Chem. 2011, 128, 330-337. [CrossRef]

22. Azarnia, S.; Boye, J.I.; Warkentin, T.; Malcolmson, L. Changes in volatile flavour compounds in field pea cultivars as affected by storage conditions: Effect of storage on flavour of field peas. Int. J. Food Sci. Technol. 2011, 46, 2408-2419. [CrossRef]

23. Ullrich, F.; Grosch, W. Identification of the most intense volatile flavour compounds formed during autoxidation of linoleic acid. Z. Für Lebensm. Unters. Und Forsch. 1987, 184, 277-282. [CrossRef]

24. Zhang, C.; Hua, Y.; Li, X.; Kong, X.; Chen, Y. Key volatile off-flavor compounds in peas (Pisum sativum L.) and their relations with the endogenous precursors and enzymes using soybean (Glycine max) as a reference. Food Chem. 2020, 333, 127469. [CrossRef] [PubMed]

25. Sithole, R.; McDaniel, M.R.; Goddik, L.M. Rate of Maillard Browning in Sweet Whey Powder. J. Dairy Sci. 2005, 88, 1636-1645. [CrossRef]

26. Boon, C.S.; McClements, D.J.; Weiss, J.; Decker, E.A. Factors Influencing the Chemical Stability of Carotenoids in Foods. Crit. Rev. Food Sci. Nutr. 2010, 50, 515-532. [CrossRef] [PubMed]

27. Trikusuma, M. Impact of Processing and Storage to the Flavor Profile of Pea Protein Beverages. Ph.D. Thesis, Ohio State University, Columbus, OH, USA, 2018.

28. Wong, K.H.; Abdul Aziz, S.; Mohamed, S. Sensory aroma from Maillard reaction of individual and combinations of amino acids with glucose in acidic conditions. Int. J. Food Sci. Technol. 2008, 43, 1512-1519. [CrossRef]

29. Gray, J.I. Measurement of lipid oxidation: A review. J. Am. Oil Chem. Soc. 1978, 55, 539-546. [CrossRef]

30. Daoud, S.; Waschatko, G.; Bou-Maroun, E.; Cayot, P. Fast, direct and in situ monitoring of lipid oxidation in an oil-in-water emulsion by near infrared spectroscopy. Anal. Methods 2020, 12, 3098-3105. [CrossRef]

31. Majchrzak, T.; Wojnowski, W.; Wasik, A. Revealing dynamic changes of the volatile profile of food samples using PTR-MS. Food Chem. 2021, 364, 130404. [CrossRef]

32. TGSC The Good Scents Company Search Page. Available online: http://www.thegoodscentscompany.com/search3.php?qName= 13360-65-1\&submit. $x=0 \&$ submit. $y=0$ (accessed on 2 October 2018).

33. Ferreira, V. A new classification of perceptual interactions between odours to interpret complex odour mixtures. In Proceedings of the Weurman Symposium, Dijon, France, 4 May 2021.

34. Brattoli, M.; De Gennaro, G.; De Pinto, V.; Demarinis Loiotile, A.; Lovascio, S.; Penza, M. Odour Detection Methods: Olfactometry and Chemical Sensors. Sensors 2011, 11, 5290-5322. [CrossRef]

35. Fischer, E.; Cachon, R.; Cayot, N. Effects of Extraction Ph on the Volatile Compounds from Pea Protein Isolate: Semi-Quantification Method Using Hs-Spme-Gc-Ms. Food Res. Int. 2021, 110760. [CrossRef]

36. Barra, A.; Baldovini, N.; Loiseau, A.-M.; Albino, L.; Lesecq, C.; Lizzani Cuvelier, L. Chemical analysis of French beans (Phaseolus vulgaris L.) by headspace solid phase microextraction (HS-SPME) and simultaneous distillation/extraction (SDE). Food Chem. 2007, 101, 1279-1284. [CrossRef] 
37. Singracha, P.; Niamsiri, N.; Visessanguan, W.; Lertsiri, S.; Assavanig, A. Application of lactic acid bacteria and yeasts as starter cultures for reduced-salt soy sauce (moromi) fermentation. LWT-Food Sci. Technol. 2017, 78, 181-188. [CrossRef]

38. Steenson, D.F.; Lee, J.H.; Min, D.B. Solid Phase Microextraction of Volatile Soybean Oil and Corn Oil Compounds. J. Food Sci. 2002, 67, 71-76. [CrossRef]

39. Blagden, T.D.; Gilliland, S.E. Reduction of Levels of Volatile Components Associated with the "Beany" Flavor in Soymilk by Lactobacilli and Streptococci. J. Food Sci. 2006, 70, M186-M189. [CrossRef]

40. Lee, K.E.; Lee, S.M.; Choi, Y.H.; Hurh, B.S.; Kim, Y.-S. Comparative Volatile Profiles in Soy Sauce According to Inoculated Microorganisms. Biosci. Biotechnol. Biochem. 2013, 77, 2192-2200. [CrossRef]

41. Oomah, B.D.; Liang, L.S.Y.; Balasubramanian, P. Volatile Compounds of Dry Beans (Phaseolus vulgaris L.). Plant Foods Hum. Nutr. 2007, 62, 177-183. [CrossRef]

42. Sala, C.; Mestres, M.; Martí, M.P.; Busto, O.; Guasch, J. Headspace solid-phase microextraction method for determining 3alkyl-2-methoxypyrazines in musts by means of polydimethylsiloxane-divinylbenzene fibres. J. Chromatogr. A 2000, 880, 93-99. [CrossRef]

43. Wang, K.; Arntfield, S.D. Binding of carbonyl flavours to canola, pea and wheat proteins using GC/MS approach. Food Chem. 2014, 157, 364-372. [CrossRef]

44. Leterme, P.; Monmart, T.; Baudart, E. Amino acid composition of pea (Pisum sativum) proteins and protein profile of pea flour. J. Sci. Food Agric. 1990, 53, 107-110. [CrossRef] 